\title{
Response of Multistorey Structure with and Without of Expansion Gap for Wind Loading and Dynamic Analysis
}

\author{
Krushna Kishor Shahane ${ }^{1}$, L. G. Kalurkar ${ }^{2}$ \\ ${ }^{1}$ P.G. Student MGM's JNEC, Aurangabad, Maharashtra, India. \\ ${ }^{2}$ AssociateProfessor, the Department of Civil Engineering MGM's JNEC, Aurangabad-431002, Maharashtra, India.
}

\begin{abstract}
Now a days Buildings are analysed and designed by the different software such as Staad pro, Etabs, sap 2000 etc. The latest Practice for designing the Buildings are Etabs and Staad pro because of their best user interface. In our case the building we are analysing with the help of Staad pro by the use of Different codes for Earthquake, Wind and Service loads etc. This paper presents an investigation on behaviour of Multi-storey building with and without expansion joint by creating 8 different model which includes the Shear wall, Response spectrum analysis wind analysis etc.
\end{abstract}

Key Words: Expansion joint, shear wall, Response spectrum analysis, Wind analysis etc.

\section{INTRODUCTION}

In order to design a structure to resist wind and earthquake loads, the forces on the structure must be specified. The exact forces that will be occur during the life of the structure cannot be anticipated. Most National Building Codes identify some factors according to the boundary conditions of each building considered in the analysis to provide for life safety. Where there is another technique to resist or to minimize the ground motion effect on earthquake is to provide the expansion joints on the building. The codes say that it is compulsory to provide the expansion joint at every $45 \mathrm{~m}$ if the building is more in length. The term "expansion joint" as used refers to the isolation joints provided within a Building to permit the separate segments of the structural frame to expand and contract in response to Temperature changes without adversely affecting the building's structural integrity or serviceability. The normal practice in runways, bridges, buildings and road construction is to provide expansion joints between cutting slabs of reinforced concrete at designing intervals and at intersections with other constructions. These join $\mathrm{t}$ filers are then covered with sealing compounds. Building expansion joints are used to cover the space between components, and provide a barrier to the exterior. Expansion joints can follow complicated paths along varying materials. Copper is an excellent material for such joints, since it is easy to form and lasts a long time.

\section{PRELIMINARY DATA CONSIDERED FOR THE ANALYSIS:}

- $\quad$ Area covering (As shown in fig 01)

- Total Height of the building

- Floor to Floor Height

$$
=25 \mathrm{~m} \times 84 \mathrm{~m} \text {. }
$$$$
=32 \mathrm{~m}
$$$$
=3.2 \mathrm{~m}
$$

- COLUMN DETAILS:

- Central column $=300 \times 750 \mathrm{~mm}$

- Outer corner column $\quad=300 \times 650 \mathrm{~mm}$

- Outer peripheral column $\quad=300 \times 600 \mathrm{~mm}$

- BEAM DETAILS:

- Outer Beams $\quad=300 \times 450 \mathrm{~mm}$

- Internal Beams $\quad=300 \times 530 \mathrm{~mm}$

3. FOLLOWING ARE CODES CONSIDERED FOR THE ANALYSIS:

- R.C.C. design : IS 456: 2000

- Earthquake design : IS1893: 2002

- Code for Dead load : IS875: Part 1

- Code for Live load : IS875: Part 2

- Code for wind load : IS 875: Part 3

$1987 \& 2015$

4. STAAD MODEL PREPARED -

1. Model-01 -Without Expansion wind load IS 875:2015

2. Model-02 -With Expansion wind load IS 875:2015

3. Model-03 -Without Expansion wind load IS $875: 1987$

4. Model-04 -With Expansion wind load IS 875:1987

5. Model-05 -Without Expansion wind load shear wall IS 875:2015

6. Model-06 -With Expansion wind load shear wall IS 875:2015

7. Model-07 -Without Expansion Dynamic analysis IS $875: 2015$

8. Model-08 -With Expansion Dynamic analysis IS 875:2015

\section{EARTHQUAKE DETAILS}

- ZONE : IV(DELHI)

- ZONE FACTORE

- IMPORTANCE FACTOR : 1.5

- TIME PERIOD IN STATIC X :0.57

- TIME PERIOD IN STATIC Y :0.31 


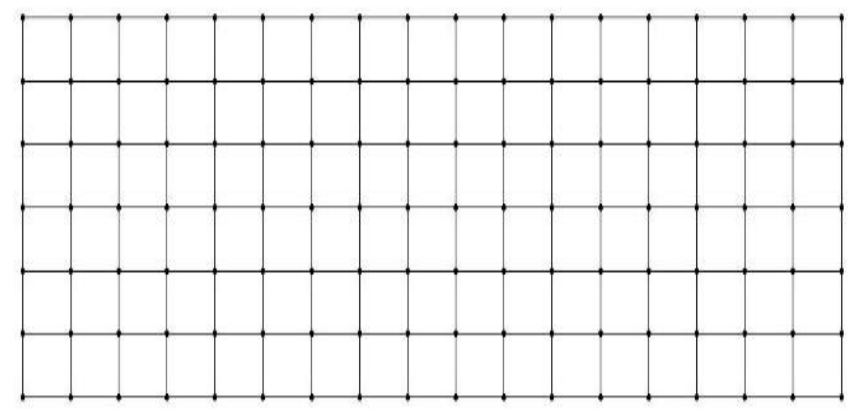

FIG: SHOWS THE PLAN OF THE BUILDING

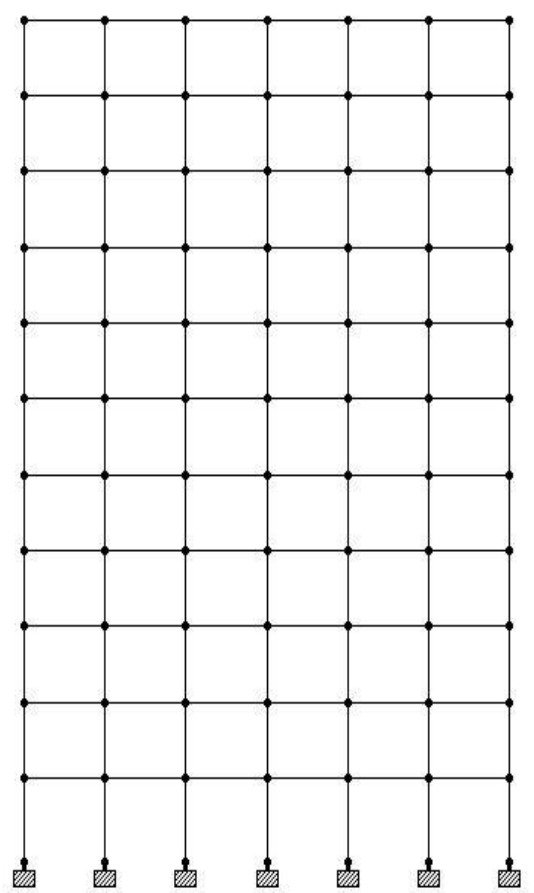

FIG: SHOWS THE ELEVATION

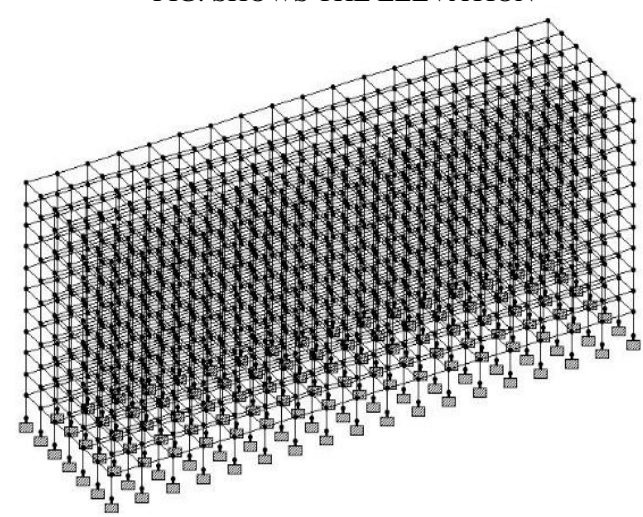

FIG: SHOWS THE 3D MODEL IN STAAD PRO

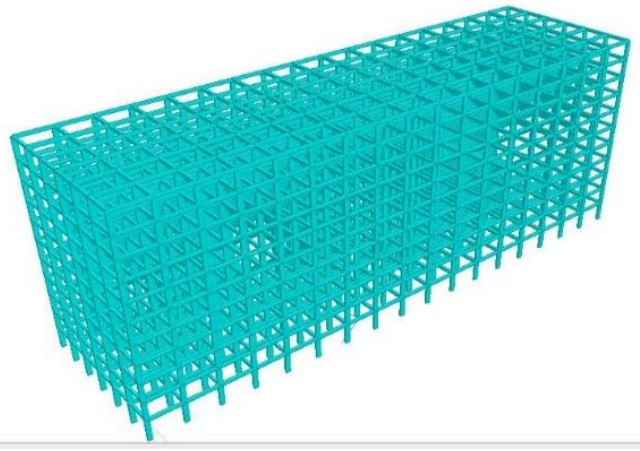

FIG: SHOWS THE EXTRUDED VIEW IN STAAD PRO

6. RESULTS: -

Table1. MODEL TIME PERIOD FOR THE DYNAMICLOAD CONSIDERATION WITH AND WITHOUT EXPANSION JOINTS

\begin{tabular}{|l|l|l|l|}
\hline SR.NO & MODE & TIMEPERIOD IN & TIMEPERIOD IN \\
& & SECONDS & SECONDS \\
& & WITHOUT & WITH \\
& & EXPANSION & EXPANSION \\
& & JOINT & JOINTS \\
\hline 1. & MODE 01 & 1.96 & 2.34 \\
\hline 2. & MODE 02 & 1.87 & 2.30 \\
\hline 3 & MODE 03 & 1.41 & 2.11 \\
\hline
\end{tabular}

Table2. BASE SHEAR DETAILS

\begin{tabular}{|c|c|c|}
\hline LOAD CASES & $\begin{array}{c}\text { WITHOUT EXPANSION } \\
\text { JOINT }\end{array}$ & $\begin{array}{c}\text { WITH } \\
\text { EXPANSION } \\
\text { JOINT }\end{array}$ \\
\hline $\begin{array}{c}\text { BASE SHEAR } \\
\text { FOR EQX }\end{array}$ & $2111 \mathrm{KN}$ & $1838 \mathrm{KN}$ \\
\hline $\begin{array}{c}\text { BASE SHEAR } \\
\text { FOR EQZ }\end{array}$ & $1570 \mathrm{KN}$ & $1387 \mathrm{KN}$ \\
\hline
\end{tabular}

Table3. MAXIMUM NODAL DISPLACEMENT WITHOUT EXPANSION JOINT

\begin{tabular}{|l|l|l|l|l|}
\hline $\begin{array}{l}\text { SR. } \\
\text { NO }\end{array}$ & $\begin{array}{l}\text { LOAD } \\
\text { CASE } \\
{[1987]}\end{array}$ & $\begin{array}{l}\text { IS 875-3 } \\
{[2015]}\end{array}$ & $\begin{array}{l}\text { MODEL } \\
\text { WITH } \\
\text { SHEAR } \\
\text { WALL }\end{array}$ \\
\hline 1. & DL & 11.599 & 11.599 & 11.59 \\
\hline 2. & LL & 1.112 & 1.112 & 1.108 \\
\hline 3 & $\begin{array}{l}\text { WIND } \\
\text { X+VE }\end{array}$ & 3.25 & 2.27 & 1.28 \\
\hline 4 & $\begin{array}{l}\text { WIND } \\
\text { X-VE }\end{array}$ & 3.25 & 2.27 & 1.28 \\
\hline 5 & $\begin{array}{l}\text { WIND } \\
\text { Z+VE }\end{array}$ & 21.77 & 15.208 & 9.93 \\
\hline 6 & $\begin{array}{l}\text { WIND } \\
\text { Z-VE }\end{array}$ & 21.77 & 15.208 & 9.93 \\
\hline
\end{tabular}

Table4. MAXIMUM NODAL DISPLACEMENT WITH EXPANSION JOINT.

\begin{tabular}{|l|l|l|l|l|}
\hline $\begin{array}{l}\text { SR. } \\
\text { NO }\end{array}$ & $\begin{array}{l}\text { LOAD } \\
\text { CASE }\end{array}$ & $\begin{array}{l}\text { IS 875-3 } \\
{[1987]}\end{array}$ & $\begin{array}{l}\text { IS 875-3 } \\
{[2015]}\end{array}$ & $\begin{array}{l}\text { MODEL } \\
\text { WITH } \\
\text { SHEAR } \\
\text { WALL }\end{array}$ \\
\hline 1. & DL & 11.599 & 11.599 & 5.34 \\
\hline 2. & LL & 1.113 & 1.113 & 0.84 \\
\hline 3 & $\begin{array}{l}\text { WIND } \\
\text { X+VE }\end{array}$ & 5.47 & 3.28 & 1.43 \\
\hline 4 & $\begin{array}{l}\text { WIND } \\
\text { X-VE }\end{array}$ & 7.85 & 5.48 & 1.43 \\
\hline 5 & $\begin{array}{l}\text { WIND } \\
\text { Z+VE }\end{array}$ & 20.19 & 14.84 & 5.78 \\
\hline 6 & $\begin{array}{l}\text { WIND } \\
\text { Z-VE }\end{array}$ & 20.19 & 14.84 & 5.78 \\
\hline
\end{tabular}




Table5. MAXIMUM NODAL DISPLACEMENT
AND WITHOUT EXPANSION JOINT WHIL
CONSIDERING DYNAMIC EARTHQUAK
\begin{tabular}{|l|l|l|l|}
\hline SR. & $\begin{array}{l}\text { LOAD } \\
\text { CASE }\end{array}$ & $\begin{array}{l}\text { MODEL } \\
\text { WITH } \\
\text { EXPANSIO } \\
\text { N JOINT }\end{array}$ & $\begin{array}{l}\text { MODEL } \\
\text { WITHOUT } \\
\text { EXPANSIO } \\
\text { N JOINT }\end{array}$ \\
\hline 1. & DL & 11.59 & 11.59 \\
\hline 2. & LL & 1.113 & 1.105 \\
\hline 7 & EQ X+ & 11.19 & 9.19 \\
\hline 8 & EQ X- & 11.19 & 9.19 \\
\hline 9 & EQ Z+ & 15.43 & 12.78 \\
\hline 10 & EQ Z- & 15.43 & 12.78 \\
\hline
\end{tabular}

7.GRAPH:

\section{1] Time period}

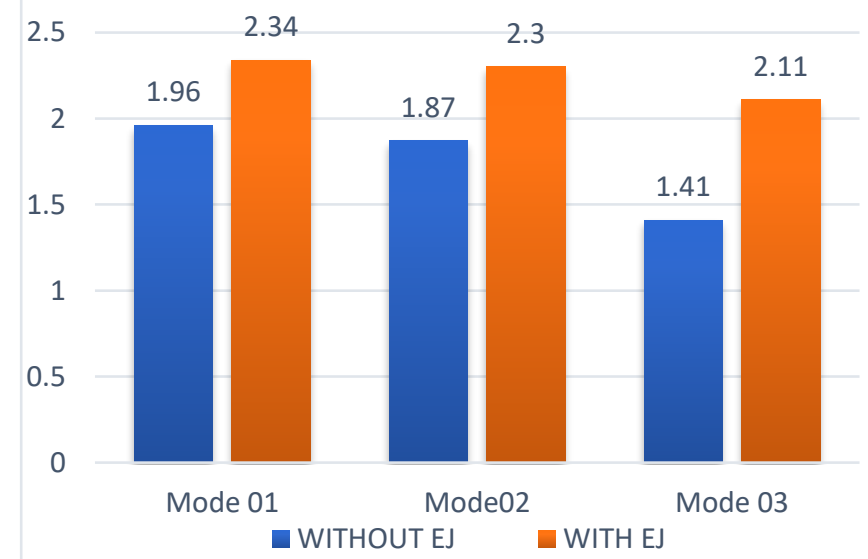

02] Base shear:

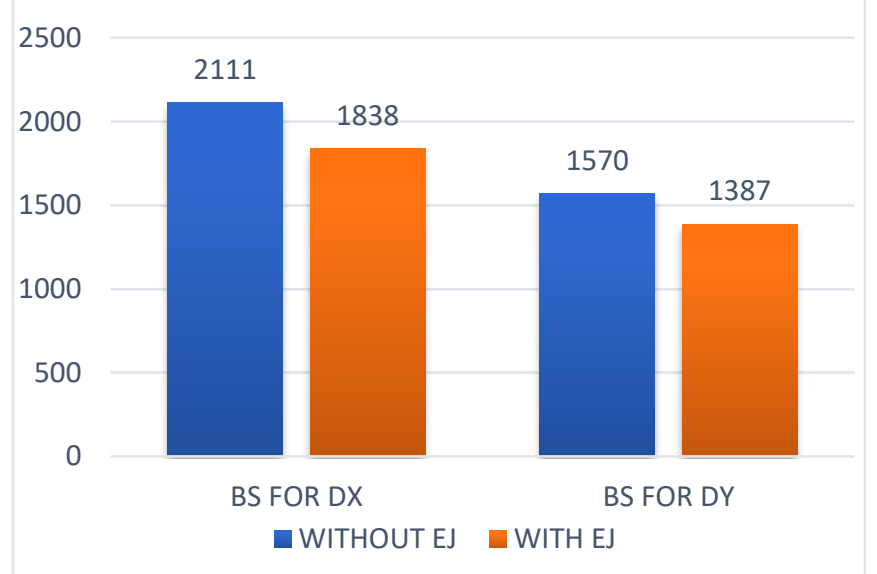

03] NODAL DISPLACEMENT [WITHOUT EXPANSION JOINT]

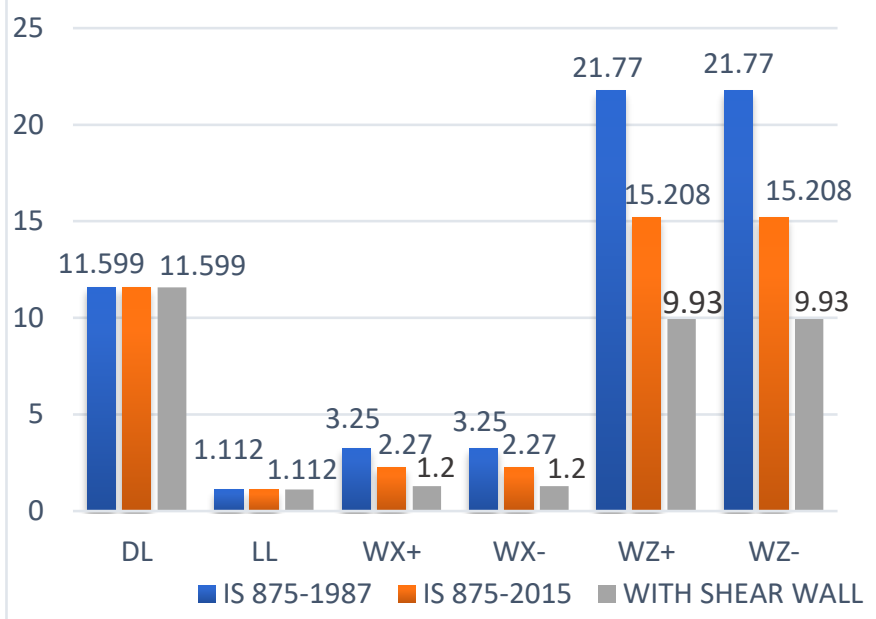

04] NODAL DISPLACEMENT [WITH EXPANSION JOINT]

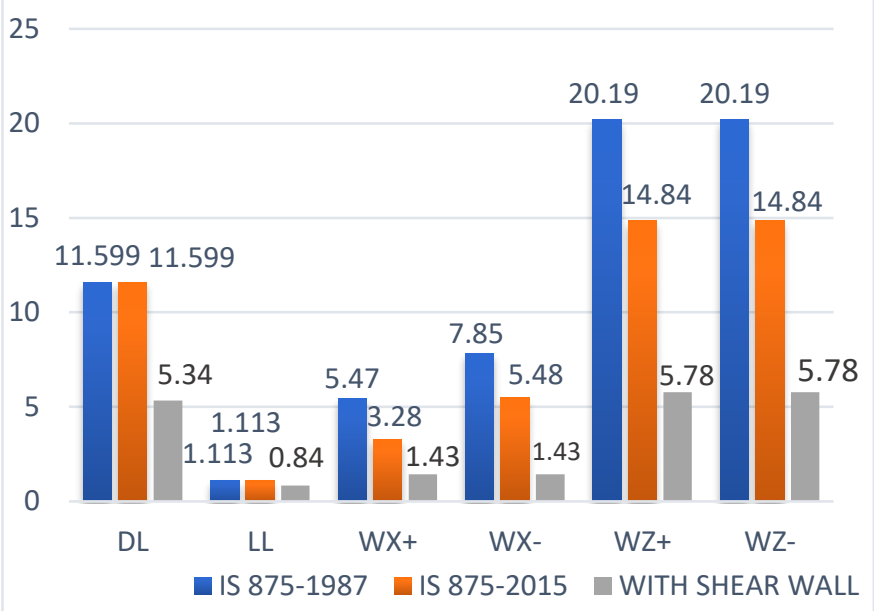

05] NODAL DISPLACEMENT[WITH AND WITHOUT EXPANSION JOINT] WHILE CONSIDERING DYNAMIC EARTHQUAKE

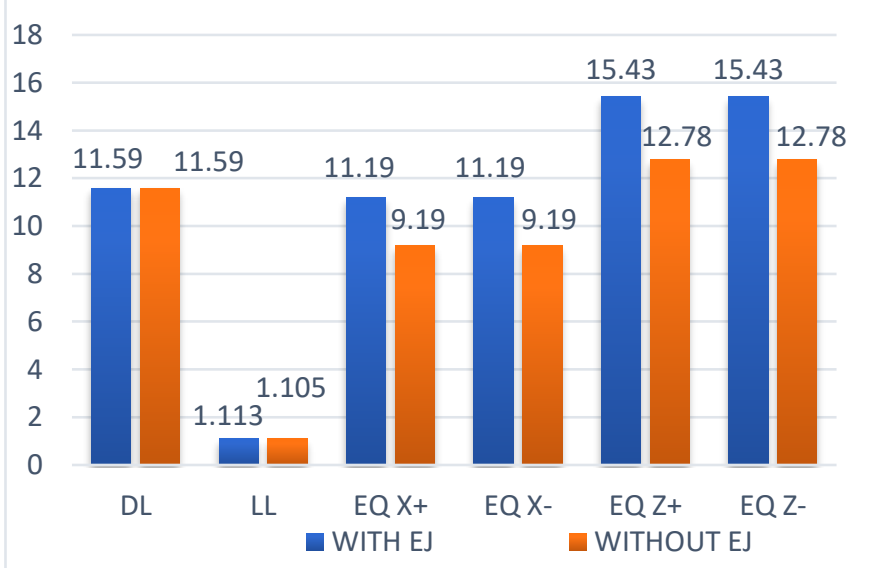




\section{CONCLUSIONS}

Following are the conclusion we have obtained from above analysis results are: -

1. Time period

In case of Time period the values where obtained for without Expansion joint model is 1.96,1.86,1.41 in first, second and third mode is lower than the Model time period obtained in model with Expansion joint is [2.34,2.30,2.11] for First, second and third mode respectively as shown in table 01 . Which means that while using is Expansion joint in the model the building will take more time to oscillate for all three modes when comparing with without expansion joint building model.as shown in table 01 .

2. Base shear

Base shear values are in Static $\mathrm{X}$ direction is $2111 \mathrm{kN}$ in Normal building model without expansion joint and for the building model using Expansion joint the base shear values are $1838 \mathrm{kn}$ which means the base shear values are reducing While using expansion joint in the building model.as shown in table 02 .

3. Nodal Displacement

A] While considering the IS 875-1987 and 875-2015 for the wind load the obtained results indicate that there is no measure different in the Displacement but the values obtained by using $875-2015$ are quite lower than that of is 875-1987 as shown in table.03,04 in Wind $\mathrm{x}$ and Wind Z direction.

B] In case of Shear wall the Nodal displacement values are getting reduces by almost $50 \%$ because the shear wall having the in plane as well as outoff plane stiffness due to that the displacement is reduces as shown in the table 03,04 above.

C] If earthquake is consider in both model of with and without Expansion joint the displacement values are increased by almost $30 \%$ in EX, EZ direction in the model where Expansion joints are used as shown in the table 5 above.

\section{REFERENCES}

[1] K. Sai ramya "study of structural behaviour of a framed c, t, 1, rectangular structures with and with out considering temperature stresses and expansion joints".

[2] Dr. B. Sujatha, B Anil Kumar "effect of expansion joints on dynamic analysis of structure".

[3] Anjana c jain, ananya john "Seismic analysis of expansion gap for multistoried buildings".

[4] Junaid aziz, m. A. Azeem "Comparative Study of a R.C.C Structure for the Elimination of Expansion Joint Subjected to Temperature Stresses".

[5] Dr. Karthiyaini S "Investigation of flat slab structures With and without expansion joints For thermal stresses".

[6] Khaled M. Heiza, Magdy A. Tayel "Comparative Study of The Effects of Wind and Earthquake Loads on High-rise Buildings".

[7] Shilpa Nirman Thilakarathna "The Effect of Wind Loads on the Seismic Performance of Tall Buildings".

[8] Yogesh katkar "Comparative study of wind load effect on high rise building".

[9] Mahesh Ram Patel, R.C. Singh "analysis of a tall structure using staad pro providing different wind intensities as per 875 part-III."

[10] B. Shankar "seismic \& wind evaluation of g+10 Residential building".

[11] Kilari Lakshmi Kanth Patrudu "Comparative Analysis for Two Different Wind Speeds for A G+10 Storey Structure".

[12] Potnuru Manoj "Wind Analysis of a Multi Storied Building with Basic Wind Speeds".

[13] Venkanna, Potlapelli. Avinash "Effect of wind on tall building frame - influence of aspect ratio".

[14] Vikrant Trivedi, Sumit Pahwa "Wind Analysis and Design of G+11 Storied Building Using STAAD-Pro".

[15] A. A. Kale, S. A. Rasa "Seismic \& Wind Analysis of Multistory Building: A Review".

[16] Imam Usman Shekh, Udaysinh Redekar "Analysis, Design and Estimation of $\mathrm{G}+7$ Storey Building Structure by using IS Code Methods and by Software's".

[17] Anoop Singh, Vikas Srivastava "Seismic Analysis and Design of Building Structures in STAAD Pro".

[18] Aneeket T. Patil and Sachin B. Kadam "Behaviour of Multistorey Building under the Effect of Wind and Earthquake for Different Configuration of Shear Wall".

[19] Azlan Adnan, Suhana Suradi "comparison on the effect of earthquake and wind loads on the Performance of reinforced concrete buildings".

[20] Ashish Sadh, Ankit Pal "A Literature Study of Wind Analysis on High Rise Building".

[21] Udaya bala k1, manish kumar gupta "dynamic analysis of multistorey building".

[22] M V Naresh, K J Brahma Chari "Study on Static and Dynamic Analysis of Multi-storied Building in Seismic Zones".

[23] By matthew D. Brady, P.e. "Expansion Joint Consider for Buildings". 